\title{
Content of available forms of nitrogen, potassium and phosphorus in ornithogenic and other soils of the Fildes Peninsula (King George Island, Western Antarctica)
}

\section{Evgeny Abakumov}

Department of Applied Ecology, Faculty of Biology, Saint Petersburg State University, $16^{\text {th }}$ Liniya V. O., 29, Saint Petersburg, 199178, Russian Federation

Address correspondence and requests for materials to Evgeny Abakumov, e_abakumov@mail.ru

\begin{abstract}
Maritime Antarctica is an interesting object for soil scientists because most of them nowadays or recently were exposed to ornitogenic effect. Soils of the Fildes Peninsula have been investigated in terms of chemical composition and available nutrients concentration. Four groups of soils with various ornitogenic effect were selected for chemical analyses: current ornitogenic soils, soils of former birds habitats - organogenic mates, natural soils without current evident bird effect - Lithosols and Technosols. Ornitogenic effect is evident in soil formation in three types of soils investigated. The maximum effect of organic matter transportation and accumulation is pronounced in Ornitogenic soils and Organogenic mat. The last one are considered as recently been colonized by birds and this fact was the reason for initiation of formation of organogenic mats due to accumulation of nutrients. Some residual effect of birds can be revealed in Lithosols, where increased content of ammonium ions and available phosphorus was fixed. Thechnosols as soils constructed from local mineral grounds have no any evidences of ornitogenic accumulation. We suggest that, majority of soils, situated on Fildes peninsula recently were exposed to ornitogenic effect. Ornitogenic effect resulted in formation of modern soil cover of the Fildes Peninsula.
\end{abstract}

Keywords: Antarctica, ornithogenic soils, nutrients, nitrogen, phosphorus, po-

Citation: Abakumov, E. 2018. Content of available forms of nitrogen, potassium and phosphorus in ornithogenic and other soils of the Fields Peninsula (King George Island, Western Antarctica). Bio. Comm. 63(2): 109-116. https://doi.org/10.21638/ spbu03.2018.203

Author's information: Evgeny Abakumov Dr. Sci., Professor, orcid.org/0000-00025248-9018

Manuscript Editor: Prof. Cezary Kabala, Institute of Soil Science and Environmental Protection, Wroclaw University of Environmental and Life Sciences, Wroclaw, Poland

Received: February 19, 2018;

Revised: June 11, 2018;

Accepted: June 16, 2018;

Copyright: (c) 2018 Abakumov. This is an open-access article distributed under the terms of the License Agreement with Saint Petersburg State University, which permits to the authors an unrestricted distribution and self-archiving free of charge.

Funding: This work was supported by the Russian Foundation of the Basic Research (projects No 16-34-60010 and No 18-04-00900).

Competing interests: The author has declared that no competing interests exist. tassium.

\section{Introduction}

Soils of the Antarctic region are very diverse and represent numerous orders and types. The extreme conditions of soil formation in this region result in the formation of weakly developed profiles in conditions of organic remnants deficit. Normally pedogenic processes are occur mainly by transformation of organic remnants within the mineral matrix with essential fine-earth content. At the same time, there are many soils and soil-like bodies in extreme environments that form from the accumulation of zoogenic organic matter on relatively unweathered parent rocks with a low fine earth portion. Antarctic soils have been investigated by many researchers (Kubiena, 1970; Campbell and Claridge, 1987; Bockheim and Ugolini, 1990; Zhao, 2000; Parnikoza et al., 2007, 2016; Korsun et al., 2008; Mergelov et al., 2012; Lupachev and Abakumov, 2013; Abakumov, Gagarina, Sapega, and Vlasov, 2013; Abakumov, Parnikoza, Vlasov, and Lupachev, 2016; Abakumov, 2017). It was shown that areas occupied by soils are concentrated in ice- and snow-free areas (Bockheim, 2015), which are estimated to make up $0.35 \%$ of Antarctica's total area, $44000 \mathrm{sq} \mathrm{km}$. 
Soils are mainly formed under monospecies populations of fungi, lichens, mosses and vascular plants. Multispecies ecosystems are also described as a significant source of soil organic matter. Meanwhile, the low intensity of photosynthesis and low productivity of ecosystems result in relatively low accumulation of humus and raw organic matter (Campbell and Claridge, 1987; Abakumov, 2010). In these conditions, organic matter of ornithogenic origin became a key factor in initialization of soil formation. Classical soils, formed under plants, are represented by Leptosols, Gleysols, Histosols, Cryosols and others (WRB, 2014). Besides them, the major representative of soil in Antarctica are ornithogenic soils. There is verificator "Ornithic" in the WRB classification system (WRB, 2014), but there is no special type of ornithogenic soils in this classification. Ornithogenic material is material with a strong morphological and chemical influence of birds on soils. The term "ornithogenic soils" has become more and more usable for those soils which have morphological and chemical features related to ornithic definition. Thus, it is possible to classify soil as Ornithic Leptosols, Ornithic Cryosols, Ornithic Gleysols, etc.

Ornithogenic soils have previously been revealed in all coastal parts of Antarctica (Bockheim et al., 2015). These territories have been studied as habitats of soil fungal communities, which can be indicators of soil biological activity (Vlasov et al., 2012). In general, penguins play the most important role in organic matter accumulation, rock transformation, chemical weathering and ornithogenic soil formation (Simas et al., 2007; Shaefer et al., 2008). Penguin guano is enriched by organic carbon, nitrogen and phosphorus. Locations of stable guano accumulation in Antarctica are known as penguin (or other bird) rookeries and single nest places. They occupy different levels of landforms, and therefore redistribution of organic matter in the landscape becomes possible (movement of guano leachates from hills to valleys). The guano accumulations affect soils not only in vertical scale, but also play an important role in initial accumulation of biogenic elements in geochemically subordinated positions. As a result, the soils of the coastal zone of Antarctica have been subjected to a direct or indirect guano impact during their history. This is the most characteristic feature of soils formed in the maritime Antarctic and in rookeries in the coastal zone of Eastern Antarctica. The phenomenon of postornithogenic succession has been described by many scientists (Ramsay, 1983; Simas, 2007; Abakumov and Mukhametova, 2014). On exposed rocks with severe conditions for plant growth, an accumulation of ornithogenic organic matter leads to development of so-called "ornithogenic" lichens (e.g. Caloplaca) and nitrophilous algae Prasiola crispa (Lightfoot) Kützing.

In areas with more favorable conditions for the development of the various formations of Antarctic terrestrial vegetation, fairly simple ecosystems can form, with the participation of mosses, lichens, and in particularly favorable conditions - vascular plants, such as Deshampsia antarctica Desv (Kozeretska et al., 2010). So, the bird's biogeochemical activity is known as the reason for intensive soil development in the Antarctic environment (Simas et al., 2007). The second aspect is the direct transportation of the vegetative parts and diasporas of plants from new places or from the coastal part to the central parts of oases, previously unaffected by these species. This is an outstanding example of the effect of birds on local biodiversity, plant expansion in territories following glacial retreat, and soil processes intensification in Antarctica (Parnikoza et al., 2016).

So, the ornithogenic effect on soils can be very different: direct effect of guano on soils; indirect effect, expressed in redistribution of guano leachate in spatial scale and redistribution of seedlings in ecosystems due to ornitohoria. A geochemical effect can by evident or may be postponed for a long time in soils which are not currently occupied by birds. That is why this work was intended to compare nutrient content in soils with differently pronounced ornithogenic effect.

\section{Materials and methods}

\section{STUDY SITES}

King George Island is the largest in the South Shetlands archipelago at about $1400 \mathrm{~km}^{2}$ (Fig. 1). Only about 5\% of its area is free of ice (Rakusa-Suszczewski, 2002). The Fildes Peninsula and Ardley Island together (around $33 \mathrm{~km}^{2}$ ) comprise the second largest ice-free area of the South Shetland Islands and the largest on King George Island. Gentle topography dominates the Fildes Peninsula, with a wide central plain and several others at different altitudes. It is a tableland made up of old coastal landforms with numerous rocky outcrops and an average height of $30 \mathrm{~m}$ a.s.l. (Michel et al., 2014).

According to Smellie, Pankhurst, Thomson, and Davies (1984), this area mainly consists of lavas with small outcrops of tuffs, volcanic sandstones and agglomerates. The climate here is cold, moist and maritime with a mean annual air temperature of $-2.2^{\circ} \mathrm{C}$ and mean summer air temperatures above $0^{\circ} \mathrm{C}$ for up to four months (Wen, Xie, Han, and Lluberas, 1994). The mean annual precipitation is $350-500 \mathrm{~mm} / \mathrm{yr}$. Fildes Peninsula and Ardley Island are among the first areas in Maritime Antarctica to become ice-free after the last glacial maximum (Birkenmajer, 1990). The Fildes Peninsula was covered by glaciers from 8000 to 5000 years BP (Mausbacher, 1989; Michel et al., 2014). The basins of most lakes are over-deepened glacial basins, and the valleys of the largest streams are glacial troughs - both are located along fractures. After the glacial erosive phase, glacial retraction led to the Holocene glacioisostatic and tectonic up- 


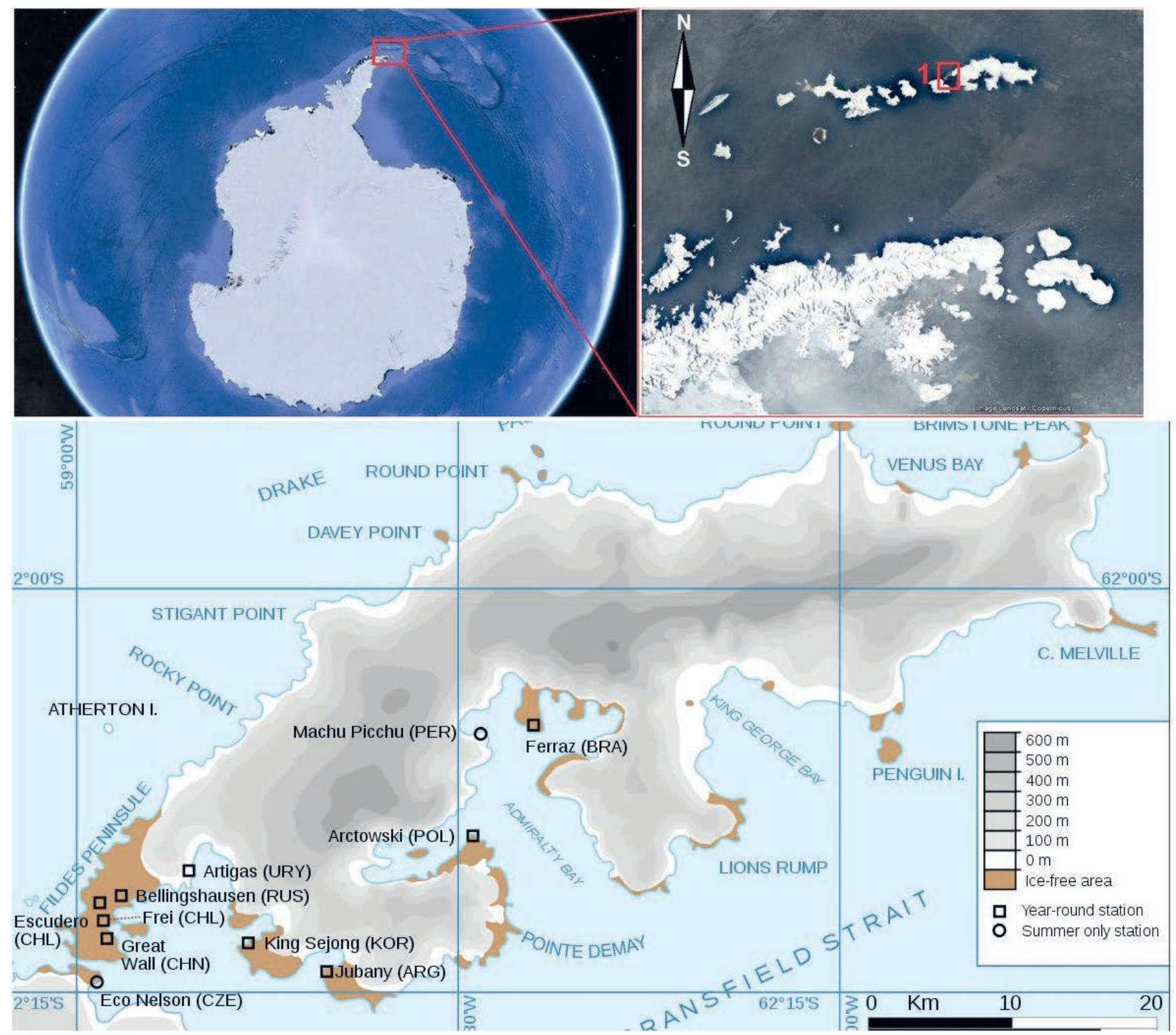

Fig. 1. Location of King George Island

lift and favored the occurrence of paraglacial and periglacial processes such as frost weathering, gelifluction, cryoturbation and nivation (Simonov, 1977; Jeong, 2006; Navas et al., 2008; López-Martínez et al., 2012).

The patterned ground in this region dates from 720 to 2640 years BP. In the South Shetland Islands, permafrost is sporadic or non-existent at altitudes below $20 \mathrm{~m}$ a.s.l., and occurs more or less discontinuously in altitudes from 30 to $150 \mathrm{~m}$ a.s.l. (Bockheim et al., 2013). Mosses, lichens, and algae are common here, along with two vascular plants (Deschampsia antarctica and Colobanthus quitensis). Penguins, seals, and seabirds are common in coastal areas and have significant effects on soil development. Major cryogenic surface-forming processes here are frost creep, cryoturbation, frost heaving and sorting, gravity and gelifluction (Michel et al., 2014). Eight separate sites on the Fildes peninsula have been collectively designated an Antarctic Specially Protected Area (ASPA 125), largely because of their paleontological values (Management plan..., 2009).

\section{SAMPLING STRATEGY}

Soils were sampled from $20 \times 20 \mathrm{~cm}$ soil pits at depths of $0-10 \mathrm{~cm}$. The Edelman drill (modification for soils) with stainless nozzle (prewashed with acetone) was used for sampling. The samples were stored in double sterile plastic bags, labeled and transported to the laboratory. The samples were air-dried at room temperature, separated from roots and debris, and passed through a $2-\mathrm{mm}$ plastic sieve prior to chemical analysis. All soil samples were divided into 4 groups: 1 ) ornithogenic soils; 2 ) organogenic mats; 3) Leptosols without evident direct effect of bird activity, and 4) soils affected directly or indirectly by 
Table 1. Sample list

\begin{tabular}{|c|c|c|c|}
\hline $\begin{array}{l}\text { Sample } \\
\text { code }\end{array}$ & Coordinates & Landform & Soil \\
\hline 1 & $62.1133,9,058.55483$ & Marine terrace close to Neftebasa & Leptosol, Ornitic, A \\
\hline$\frac{2}{3}$ & $621236,2,05855$ 43,3 & Marine terrace, Ardley peninsula & Lithosol, Ornitic, A \\
\hline 4 & $62.13077,058.45550$ & Marine terrace & Leptosol, Ornitic, A \\
\hline 5 & $62.10583,058.58498$ & Ridge, covered by nest of Skua & Leptosol, Ornitic, A \\
\hline 6 & $62.11080,058.58300$ & $\begin{array}{l}\text { Valley on the way to Drake passage, proluvial sediments, covered } \\
\text { by mats }\end{array}$ & Histic Fluvisols, A \\
\hline 7 & $62.10518,058.55 .053$ & Hills close to Artigas station, covered by mat & Regosol, C \\
\hline 8 & $62.12400,05856166$ & Flat upland covered by mat, Ardley Island & Cryosol, A \\
\hline 9 & $62.12400,058.56471$ & Flat upland covered by mat, Ardley Island & Cryosol, A \\
\hline 10 & \multirow{2}{*}{$62.09147,058.55167$} & \multirow{2}{*}{ Moraine hills close to Collins glacier } & \multirow{2}{*}{ Regosol, A and C horizons } \\
\hline 11 & & & \\
\hline 12 & $62.14480,058.58454$ & $\begin{array}{l}\text { Ridge, Nelson Island, covered by algae and lichens, possible former } \\
\text { presence of birds }\end{array}$ & Leptosol, A \\
\hline 13 & \multirow{2}{*}{$62.10450,058.58525$} & \multirow{2}{*}{ Marine terrace in Tylenya bay, moss cover } & \multirow{2}{*}{ Leptosol A } \\
\hline 14 & & & \\
\hline 15 & $62.11024,058.5134 .0$ & $\begin{array}{l}\text { Ridge covered by Deshampsia antrarctica, possible former presence } \\
\text { of birds }\end{array}$ & Leptosol A and C horizons \\
\hline 16 & \multirow{2}{*}{$62.11519,058.57199$} & \multirow{2}{*}{ Former waste disposal close to Bellinshausen station } & \multirow{2}{*}{$\begin{array}{l}\text { Technic Cryosol, topsoil, } \\
2 \text { samples }\end{array}$} \\
\hline 17 & & & \\
\hline 18 & $62.11483,058.57476$ & Bellinshausen station, close to old diesel station & Technic Cryosol, topsoil \\
\hline 19 & 62.09146, 05855 15,9 & Territory of Bellinshausen station & Technic Cryosol, topsoil \\
\hline 20 & $62.09146,058.55159$ & Territory of Bellinshausen station & Technic Cryosol, topsoil \\
\hline
\end{tabular}

humans (waste disposal, station activity and mechanical disturbance). In total, 20 samples were analyzed. Soil types were identified on the basis of morphological field description of whole profiles (IUSS Working Group WRB, 2015), in spite of the fact that samples were collected only from the superficial layers. Soils from Elephant Island were mostly Turbic Cryosols and Leptosols under sparse mosses and lichen vegetation cover. The average thickness of the soil profiles was about $15-25 \mathrm{~cm}$. Soils of King George Island were represented by six soil groups (IUSS Working Group WRB, 2015): Leptosols, Cryosols, Fluvisols, Regosols, Histosols and Technosols. This corresponds well with previously published data (Navas et al., 2008). Soil was sampled from the non-living part of organogenic or organo-mineral layers.

Ornithogenic soils studied here were mostly made up of polypedons under transported plant material. Birds use it for nest building, and this activity results in accumulation of essential portions of organic matter in the uppermost layers (up to 25\%). We suggest that bird transport activity can result in the accumulation of additional portions of trace elements. Background mineral soils without evident bird activity were studied in pristine (Turbic Cryosols, Cambisols, Regosols, Leptosols) and humanaffected environments (Technic Turbic Cryosols and soil in the area of Bellingshausen station and former waste disposals). Thus, we can compare the levels of trace elements accumulation in four groups of soils - two of these serve as the reference (pristine soils of Elephant and King George); the other two are affected by geochemical activity of ornithogenic or anthropogenic origin. The average thickness of $\mathrm{O}$ and $\mathrm{A}$ horizons variate in investigated soils was about 3-8 cm. Only in the case of Histic Fluvisol, the thickness of the AO horizon was $12 \mathrm{~cm}$.

\section{LABORATORY METHODS}

Soil samples were air-dried, ground and passed through a 2-mm sieve. $\mathrm{pH}$ values were determined in soil-water or soil- $\mathrm{CaCl}_{2}$ solution; the ratio of soil and solution was 1:2.5. 

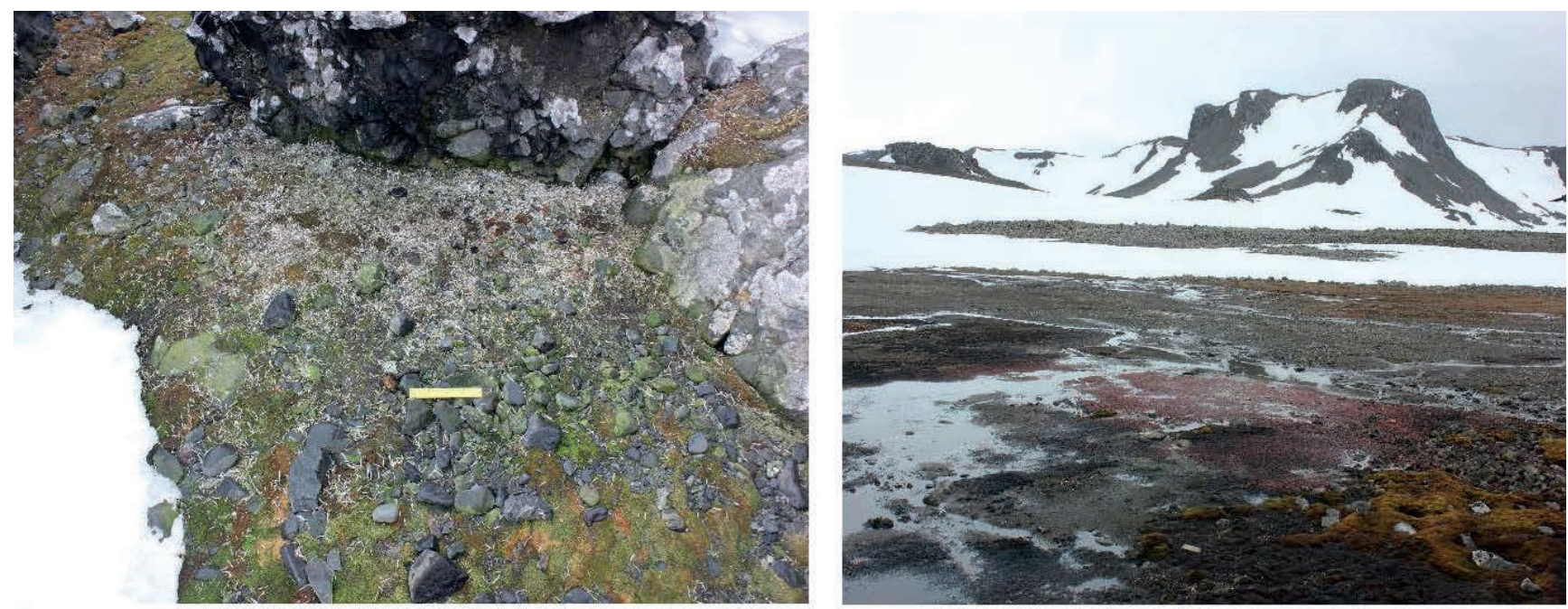

1
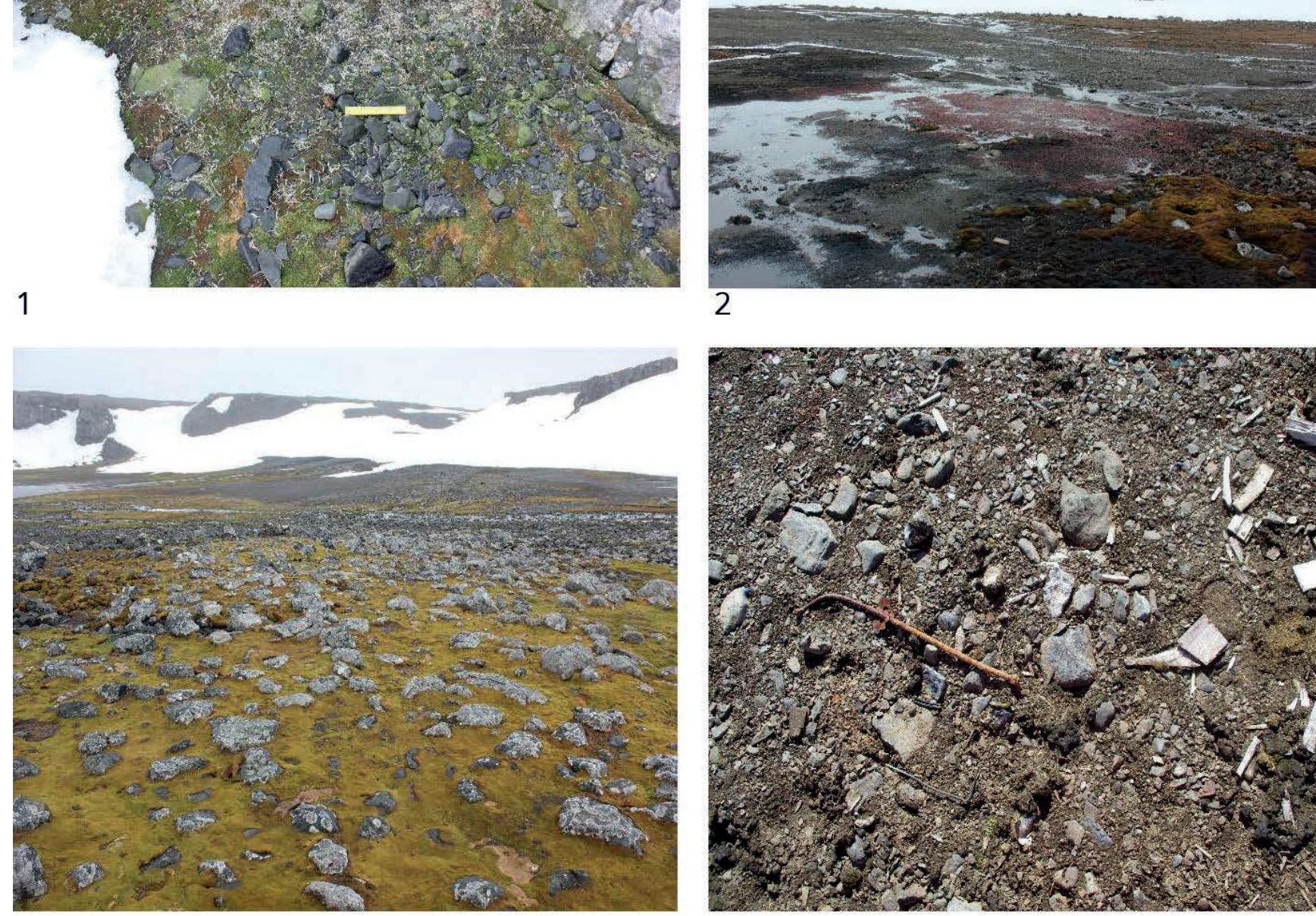

4

3

Fig. 2. Examples of soils: 1) soil under ornithogenic effect (sample 1); 2) organogenic mat (sample 6); 3) soil without pronounced ornithogenic effect (sample 13); 4) soil under the former waste disposal (sample 18)

Total organic carbon and nitrogen were determined with a C-H-N- analyzer (Euro EA3028-HT). For the extraction of ammonium nitrogen, we used $\mathrm{KCl}$ (EPA method 350.1., August 1993). Mobile phosphorus and potassium content was determined using their extraction by $0.5 \mathrm{~mol} / \mathrm{L} \mathrm{HCl}$ (Kuo, 1996). The evaluation of the main agrochemical characteristics was performed by the standard procedures recorded in GOST 54650-2011 (for evaluation of mobile phosphorus and potassium contents) and GOST 2648985 (for evaluation of ammonium nitrogen content).

\section{STATISTICS}

Statistical data treatment used STATISTICA 10.0 software (ANOVA, Statistica Base 12.6, Dell, Round Rock,
TX, USA). One-way ANOVA was applied to test the statistical significance of differences between obtained data. This method is based on estimation of the significance of average differences between three or more independent groups of data combined by one feature (factor). A post-hoc test (Fisher LSD) provides a detailed evaluation of the average differences between the analyzed groups of data. A feature of the post-hoc-test is application of intra-group mean squares for the assessment of any pair averages. Differences were significant at the $95 \%$ confidence level. Concentrations of nutrients and biogenic elements were analyzed with at least three replicates. The calculated average concentrations were provided with standard deviations $(\mathrm{a} \pm \mathrm{b})$. 
Table 2. The content of available forms of nutrients, bulk content of carbon and nitrogen and $\mathrm{pH}$ values of various soil groups.

\begin{tabular}{|c|c|c|c|c|c|c|c|c|c|}
\hline \multirow{2}{*}{$\begin{array}{l}\text { Sample } \\
\text { code }\end{array}$} & $\mathrm{P}_{2} \mathrm{O}_{5}$ & $\mathrm{~K}_{2} \mathrm{O}$ & $\mathrm{N}-\mathrm{NH}_{4}$ & $\mathrm{~N}-\mathrm{NO}_{3}$ & $\mathrm{C}$ & $\mathbf{N}$ & \multirow{2}{*}{$\mathrm{C} / \mathrm{N}$} & \multirow{2}{*}{ pHwater } & \multirow{2}{*}{ pHCaCL2 } \\
\hline & \multicolumn{4}{|c|}{$M g * k^{-1}$} & \multicolumn{2}{|c|}{$\%$} & & & \\
\hline
\end{tabular}

Ornithogenic soils

\begin{tabular}{|c|c|c|c|c|c|c|c|c|c|}
\hline 1 & 772 & 992 & 572.3 & 165.5 & 8.45 & 0.94 & 8.99 & 5.60 & 5.60 \\
\hline 2 & 29453 & 3685 & 306.2 & 201.4 & 27.63 & 5.18 & 5.33 & 6.35 & 5.30 \\
\hline 3 & 4310 & 2412,5 & 390.5 & 30.1 & 19.05 & 2.20 & 8.66 & 5.67 & 4.89 \\
\hline 4 & 1117 & 1606 & 480.8 & 29.2 & 20.04 & 1.16 & 17.13 & 4.80 & 4.80 \\
\hline 5 & 710 & 734 & 126.3 & 2.48 & 7.55 & 0.62 & 12.05 & 4.67 & 4.60 \\
\hline
\end{tabular}

Organogenic mats

\begin{tabular}{c|c|c|c|c|c|c|c|c|c}
\hline 6 & 703 & 2384 & 78 & 2.66 & 15.55 & 184 & 8.45 & 5.60 & 5.60 \\
\hline 7 & 270 & 424 & 46.9 & 2.52 & 11.52 & 2.16 & 5.33 & 5.89 & 5.43 \\
\hline 8 & 1902 & 6688,5 & 207.5 & 29.6 & 29.01 & 4.25 & 6.82 & 5.60 & 4.90 \\
\hline 9 & 172 & 1058 & 221.3 & 17.3 & 7.26 & 0.99 & 7.30 & 6.00 & 5.71 \\
\hline
\end{tabular}

Leptosols

\begin{tabular}{c|c|c|c|c|c|c|c|c|c}
\hline 10 & 1321 & 536 & 157.2 & 15.1 & 5.32 & 0.29 & 18.09 & 6.23 & 6.20 \\
\hline 11 & 3542 & 1582.5 & 1206.8 & 497.5 & 0.31 & 0.03 & 10.39 & 4.89 & 4.10 \\
\hline 12 & 1594 & 1669 & 68.9 & 4.25 & 4.89 & 0.79 & 6.15 & 5.76 & 5.71 \\
\hline 13 & 689 & 1428 & 227.2 & 4.43 & 15.39 & 0.72 & 21.13 & 5.57 & 5.20 \\
\hline 14 & 4292 & 5031 & 662.6 & 92.5 & 10.16 & 0.84 & 11.98 & 4.90 & 4.21 \\
\hline 15 & 2582 & 842 & 448.5 & 322.2 & 6.66 & 0.81 & 8.20 & 4.70 & 4.35 \\
\hline
\end{tabular}

Technic Cryosol

\begin{tabular}{c|c|c|c|c|c|c|c|c|c}
\hline 16 & 198 & 433 & 9.69 & 1.37 & 0.66 & 0.11 & 5.74 & 6.83 & 5.28 \\
\hline 17 & 277 & 325 & 9.57 & 1.42 & 0.67 & 0.05 & 13.45 & 6.11 \\
\hline 18 & 275 & 344 & 33.6 & 2.39 & 1.02 & 0.05 & 17.75 & 4.67 & 3.89 \\
\hline 19 & 707 & 263 & 121.4 & 41.6 & 1.91 & 0.17 & 11.02 & 5.78 & 5.15 \\
\hline 20 & 719 & 962 & 9.51 & 2.61 & 0.38 & 0.03 & 9.79 & 5.54 & 5.21 \\
\hline
\end{tabular}

\section{Results and discussion}

Data of total organic carbon and nitrogen content and $\mathrm{pH}$ values are provided in Table 2. All soils of the Fildes peninsula investigated in this work are slightly acidic, which corresponds with numerous previous studies (Tatur, 2002; Zhu et al., 2009; Pereira et al., 2013). The highest average carbon content was typical for ornithogenic soils. This is caused by the enrichment of terrestrial ecosystems by bird-transported organic matter (Zhu et al., 2009) and intensification of plant growth and production under the influence of increased bulk nitrogen accumulation (Speir and Cowling, 1984). In general, the $\mathrm{C} / \mathrm{N}$ ratios were higher in Leptosols and Technosols, which indicates lower nitrogen content. In contrast, the $\mathrm{C} / \mathrm{N}$ ratio was lower in ornithogenic soils and organogenic mats. This il- lustrates birds' contribution in soil enrichment by mineral forms of nitrogen. The highest content of available nitrogen forms (N-NH4) was typical for Leptosols, but not in ornithogenic soil and organogenic mat. This could be an effect of deeper transformation of nitrogen-containing compounds in case of postornithogenic succession development. The last two soil groups were enriched by bulk nitrogen, but not by available forms of nitrogen ions. Mats are comparable to ornithogenic soils in terms of chemical composition because most mats were previously colonized by birds, mainly by scuas. The content of phosphorus was highest in sample № $2-$ ornithogenic soil, situated on marine terrace. Ornithogenic soil, organogenic mats and Leptosols showed increased content of phosphorus in comparison with Technosols. This also could be related to current and previous ornithogenic effect. Previously, pho- 
Table 3. Results of post-hoc test (significant values when $p<0.05$, bolded)

\begin{tabular}{l|c|c|c|c|c|c}
\hline \multicolumn{1}{c|}{ Sample group } & $\mathbf{P}_{\mathbf{2}} \mathbf{O}_{\mathbf{5}}$ & $\mathbf{K}_{\mathbf{2}} \mathbf{O}$ & $\mathbf{N}-\mathbf{N H}_{\mathbf{4}}$ & $\mathbf{N}-\mathbf{N O}_{\mathbf{3}}$ & $\mathbf{C}$ & $\mathbf{N}$ \\
\hline Ornithogenic soils/Organogenic mats & $<\mathbf{0 . 0 1}$ & $<0.06$ & $<\mathbf{0 . 0 5}$ & $<0.06$ & $<0.04$ & $<0.06$ \\
\hline Ornithogenic soils/Leptosols & $<\mathbf{0 . 0 3}$ & $<0.07$ & $<0.06$ & $<0.07$ & $<\mathbf{0 . 0 5}$ & $<0.06$ \\
\hline Ornithogenic soils/Technic Cryosol & $<0.03$ & $<0.07$ & $<0.06$ & $<0.06$ & $<0.01$ & $<0.01$ \\
\hline Organogenic mats/Leptosols & $<0.06$ & $<0.06$ & $<0.05$ & $<0.07$ & $<0.07$ & $<0.06$ \\
\hline Organogenic mats/Technic Cryosol & $<0.01$ & $<0.06$ & $<0.06$ & $<0.09$ & $<0.06$ & $<0.08$ \\
\hline Lithosols/Technic Cryosol & $<0.02$ & $<0.06$ & $<0.02$ & $<0.08$ & $<0.08$ & $<0.09$ \\
\hline
\end{tabular}

spatization was considered a key process of ornithogenic soil formation (Tatur and Keck, 1990). This process could be expressed in some cases in the formation of a group of phosphate-containing minerals (Tatur and Barczuk, 1985). Results of the post-hoc test showed (Table 2) that the most pronounced differences between the soil groups were characteristic for phosphorus and total carbon content. Accumulation of these two biogenic elements could occur as a result of ornithogenic accumulation. No evident differences in accumulation of potassium and nitrates were revealed in investigated soils. In contrast, sufficient differences in ammonia ion concentrations were revealed between ornithogenic soils and organogenic mats and pairs of ornithogenic soils and Technosols.

\section{Conclusions}

Ornithogenic effect is evident in soil formation in three types of soils investigated. The maximum effect of organic matter transportation and accumulation is pronounced in ornithogenic soils and organogenic mat. Organogenic mats are considered to have been recently colonized by birds; this initiated the formation of organogenic mats due to accumulation of nutrients. Some residual effect of birds can be revealed in Lithosols, where increased content of ammonium ions and available phosphorus was fixed. Technic Cryosol as soils constructed from local mineral grounds show no evidence of ornithogenic accumulation. We suggest that the majority of soils on the Fildes peninsula were recently exposed to ornithogenic effect, which resulted in formation of the modern soil cover of the Fildes peninsula.

\section{Acknowledgements}

The author thanks Dr. A. Lupachev for assistance in field research and providing photographs for Fig. 2 (1, 2 and 3).

\section{References}

Abakumov, E.V. 2010. The sources and composition of humus in some soils of West Antarctica Eurasian Soil Science 43(5):499-508. https://doi.org/10.1134/ S1064229310050030
Abakumov, E. 2017. Characterisation of humic acids, isolated from selected subantarctic soils by 13C-NMR spectroscopy. Czech Polar Reports 7(1):1-10. https://doi. org/10.5817/CPR2017-1-1

Abakumov, E., and Mukhametova, N. 2014. Microbial biomass and basal respiration of selected Sub-Antarctic and Antarctic soils in the areas of some Russian polar stations. Solid Earth 5:705-712. https://doi.org/10.5194/ se-5-705-2014

Abakumov, E. V., Gagarina, E. I., Sapega, V. F., and Vlasov, D. Y. 2013. Micromorphological features of the fine earth and skeletal fractions of soils of West Antarctica in the areas of Russian Antarctic stations. Eurasian Soil Science 46(12):1219-1229. https://doi.org/10.1134/ S1064229313120028

Abakumov, E. V., Parnikoza, I.Y., Vlasov, D. Y., and Lupachev, A. V. 2016. Biogenic-abiogenic interaction in antarctic ornithogenic soils; pp. 237-248 in: O. V. Frank-Kamenetskaya et al. (eds.) Biogenic-Abiogenic Interactions in Natural and Anthropogenic Systems, Lecture Notes in Earth System Sciences, Springer International Publishing, Switzerland. https://doi.org/10.1007/978-3-319-24987-2_19

Birkenmajer, K., 1990. Geology and climatostratigraphy of Tertiary glacial and interglacial successions on King George Island, South Shetland Islands (West Antarctica). Zentralblatt für Geologie und Paläontologie Teil 1 (1/2):141-151.

Bockheim, J. G. (Ed.) 2015. The Soils of Antarctica. Springer International Publishing, Switzerland, 322 pp. https://doi. org/10.1007/978-3-319-05497-1

Bockheim, J. G. and Ugolini, F. C. 1990. A review of pedogenic zonation in well-drained soils of the southern circumpolar region. Quaternary Research 34(1):47-66. https://doi. org/10.1016/0033-5894(90)90072-S

Bockheim, J., Vieira, G., Ramos, M., López-Martínez, J., Serrano, E., Guglielmin, M., Wihelm, K., and Nieuwendam, A. 2013. Climate warming and permafrost dynamics on the Antarctic Peninsula region. Global and Planetary Change 100: 215-223. https://doi.org/10.1016/j.gloplacha.2012.10.018

Campbell, I. B. and Claridge, G. G. C. 1987. Antarctica: Soils, Weathering Processes and Environment. Elsevier: Amsterdam. 368 pp.

EPA method 350.1. Determination of Ammonia Nitrogen by automated colorimetry. Revision 2.0. August 1993.

GOST 26489-85 Soils. Determination of exchangeable ammonium by CINAO method.

GOST 54650-2011 Soils. Determination of mobile phosphorus and potassium compounds by Kirsanov method modified by CINAO

IUSS Working Group WRB 2015. World Reference Base for Soil Resources 2014, update 2015. 
International soil classification system for naming soils and creating legends for soil maps. World Soil Resources Reports No. 106. FAO, Rome

Jeong, G. Y. 2006. Radiocarbon ages of sorted circles on King George Island, South Shetland Island, West Antarctica. Antarctic Science 18(2):265-270. https://doi.org/10.1017/ S0954102006000307

Korsun, S., Kozeretska, I., Parnikoza, I., Skarivska, L., Lugovska, K., and Klimenko, I. 2008. Effect of natural and anthropogenic factors on the chemical composition of soils of the King George in littoral Antarctic. Agroecological Journal 4:45-52.

Kozeretska, I. A., Parnikoza, I.Yu., Mustafa, O., Tyschenko, O. V., Korsun, S. G., and Convey, P. 2010. Development of Antarctic herb tundra vegetation near Arctowski station, King George Island. Polar Science 3(4):254-261. https://doi.org/10.1016/j.polar.2009.10.001

Kubiena, W. L. 1970. Micromorpohologic investigation of Antarctic soils. Antarctic Journal 5(4):105-106.

Kuo, S. 1996. Phosphorus; pp. 869-919 in: Bartels J. M. and Bigham J. M. (eds.). Methods of Soil Analysis, 3. Chemical Methods. Madison: Soil Science Society of America.

López-Martínez, J., Serrano, E., Schmid, T., Mink, S., and Linés, C. 2012. Periglacial processes and landforms in the South Shetland Islands (northern Antarctic Peninsula region). Geomorphology 155-156:62-79. https://doi. org/10.1016/j.geomorph.2011.12.018

Lupachev, A. V. and Abakumov, E. V. 2013. Soils of Marie Byrd Land, West Antarctica, Eurasian Soil Science 46:9941006. https://doi.org/10.1134/S1064229313100049

Management Plan for Antarctic Specially Protected Area No. 125, 2009. Measure 6, Annex., Antarctic Treaty Secretariat. Retrieved on 23/06/2018 from https://www.ats.aq/ documents/recatt/Att273_e.pdf

Mausbacher, R., Muller, J., Munnich, M., Schmidt, R. 1989. Evolution of postglacial sedimentation in Antarctic lakes (King Georges Island). Zeitschrift fur Geomorphologie 33:219-234.

Mergelov, N. S., Goryachkin, S. V., Shorkunov, I. G., Zazovskaya, E. P., and Cherkinskii, A. E. 2012. Endolithic pedogenesis and rock varnish on massive crystalline rocks in East Antarctica. Eurasian Soil Science 45(10):901-918. https:// doi.org/10.1134/S1064229312100067

Michel, R. F. M., Schaefer, C.E. G.R., López-Martínez, J., Simas, F. N. B., Haus, N. W., Serrano, E., and Bockheim, J. G. 2014. Soils and landforms from Fildes Peninsula and Ardley Island, Maritime Antarctica. Geomorphology 225:7686. https://doi.org/10.1016/j.geomorph.2014.03.041

Navas, A., López-Martínez, J., Casas, J., Machín, J., Durán, J. J., Serrano, E., Cuchi, J. A., and Mink, S. 2008. Soil characteristics on varying lithological substrates in the South Shetland Islands, maritime Antarctica. Geoderma 144(1-2):123-139. https://doi.org/10.1016/j.geoderma.2007.10.011

Parnikoza, I., Miryuta, N. Yu., Maidanyuk, D. N., Loparev, S. A., Korsun, S. G., Budzanivska, I.G., Shevchenko, T. P., Polischuk, V.P., Kunakh, V. A., and Kozeretska, I. A. 2007. Habitat and leaf cytogenetic characteristics of Deschampsia antarctica Desv. in Maritime Antarctic. Polar Science 1(2-4):121-128. https://doi.org/10.1016/j.polar.2007.10.002

Parnikoza, I., Abakumov, E., Korsun, S., Klymenko, I., Netsyk, M., Kudinova, A., and Kozeretska, I. 2016. Soils of the argentine islands, antarctica: Diversity and characteristics. Polarforschung 86(2):83-96. https://doi.org/10.2312/ polarforschung.86.2.83

Pereira, T. T. C., Schaefer, C. E. G. R., Ker J. C., Almeida, C. C., Almeida, I. C. C., and Pereira, A. B. 2013. Genesis, min- eralogy and ecological significance of ornithogenic soils from a semi-desert polar landscape at Hope Bay, Antarctic Peninsula. Geoderma 209-210:98-109. https://doi. org/10.1016/j.geoderma.2013.06.012

Rakusa-Suszczewski, S. 2002. King George Island - South Shetland Islands, Maritime Antarctic; 23-39 in: Beyer, L. and Bölter, M. (eds.), Geoecology of Antarctic Ice Free Coastal Landscapes. Springer Verlag: Berlín. https://doi. org/10.1007/978-3-642-56318-8_3

Ramsay, A. J. 1983. Bacterial biomass in Ornithogenic soils of Antarctica. Journal of Polar Biology 1: 221-225. https:// doi.org/10.1007/BF00443192

Simonov, I. M., 1977. Physical-geographic description of the fildes peninsula (South Shetland Islands). Polar Geography 1:223-242. https://doi. org/10.1080/10889377709388627

Speir, T.W. and Cowling, J. C. 1984. Ornithogenic soils of the Cape Bird adelie penguin rookeries, Antarctica. Polar Biology 2(4):199-205. https://doi.org/10.1007/BF00263625

Simas, F. N. B., Schaefer, C.E.G.R., Melo, V.F., Albuquerque-Filho, M.R., Michel, R.F.M., Pereira, V.V., Gomes, M. R. M., and da Costa, L. M. 2007. Ornithogenic cryosols from Maritime Antarctica: Phosphatization as a soil forming process. Geoderma 138(3-4):191-203. https://doi.org/10.1016/j.geoderma.2006.11.011

Shaefer, C. E. G. R., Simas, F. N. B., Gilkes, R. J., Mathison C., da Costa, L. M., and Albuquerque, A. 2008. Micromorphology and microchemistry of selected Cryosoils from maritime Antarctica. Geoderma 144(1-2):104-115. https:// doi.org/10.1016/j.geoderma.2007.10.018

Smellie J. L., Pankhurst R. J., Thomson M. R. A., Davies R. E. S., 1984. The geology of the South Shetland Islands: VI. Stratigraphy, geochemistry and evolution. Cambridge, British Antarctic Survey, 85 pp. (British Antarctic Survey Scientific Reports, 87).

Tatur, A., Keck, A., 1990. Phosphates in ornithogenic soils of the maritime Antarctic. Proc. NIPR Symp. Polar Biology 3:133-150.

Tatur, A. 2002. Ornithogenic Ecosystems in the Maritime Antarctic - Formation, Development and Disintegration; pp. 161-184 in: Beyer, L., and Bölter M. (eds.) Geoecology of Antarctic Ice-Free Coastal Landscapes. Ecological Studies (Analysis and Synthesis), vol 154. Springer: Berlin, Heidelberg. https://doi.org/10.1007/978-3-64256318-8 10

Tatur A. and Barczuk, A. 1985. Ornithogenic Phosphates on King George Island in the Maritime Antarctic; pp. 163168 in: Siegfried, W. R., Condy, P. R., and Laws, R. M. (eds.). Antarctic Nutrient Cycles and Food Webs. Springer: Berlin, Heidelberg. https://doi.org/10.1007/978-3642-82275-9 22

Vlasov, D. Yu., Zelenskaya, M.S., Kirtsideli, I.Y., Abakumov, E. V., Krylenkov, V. A., and Lukin, V. V. 2012. Fungi on natural and anthropogenic substrates in Western Antarctica. Mycology and Phytopathology 46(1):20-26.

Zhao, Ye. 2000. The soil and environment in the Fildes Peninsula of Kind George Island, Antarctica. China, Bejing. $187 \mathrm{pp}$.

Zhu, R., Liu, Y., Ma, E., Sun, J., Xu, H., and Sun, L. 2009. Nutrient compositions and potential greenhouse gas production in penguin guano, ornithogenic soils and seal colony soils in coastal Antarctica. Antarctic Science 21(5):427438. https://doi.org/10.1017/S0954102009990204

Wen, J., Xie, Z., Han, J., and Lluberas, A. 1994. Climate, mass balance and glacial changes on small dome of Collins Ice Cap, King George Island, Antarctica. Antarctic Research 5(1):52-61. 